\title{
Blunt Instruments： \\ The European Parliament's Investiture and Censure of the EU Commission
}

Jun, $\mathrm{H}$ ae-Won

(Sogang University)

〈CONTENTS〉

I. Introduction

II. The Rules for Electing and Censuring the Commission

III. Determinants of MEP Voting Behaviour in the Election/Censure of the Commission
IV. Statistical Analysis

1. Seven Votes on the Santer, Prodi and Barroso Commissions

2. The Variables

3. Results

V. Conclusion

- Keyword: European Union, Censure, Investiture, European Commission, European Parliament

\section{【ABSTRACT】}

This article investigates how the Members of the European Parliament (MEPs) make decisions on in the appointment and censure of the Commission. The key contention is that MEPs' behaviour in these votes is ultimately determined by their policy preferences. Based on this, I develop some hypotheses about MEPs' preferences on the control of the Commission. These are then tested on the voting behaviour of MEPs in the roll-call votes on the appointment of three Commissions, respectively headed by Jacques Santer, Romano Prodi and José Manuel Barroso, and the censure of the Santer Commission. The finings confirms the contention. When deciding how to vote, each MEP makes a judgment about whether policy outcomes from the EU are likely to be moved closer or further away from his/her preferences as a result of electing or removing a particular Commission. Also, the partisan affiliation of MEPs and Commission does matter. In the appointment of the Commission, the candidates for the Commission President and the Commission as a whole can draw support from three groups: MEPs from governing parties, MEPs from parties that will have Commissioners, and MEPs from ideologically 
similar party groups in the Parliament. With one commissioner per member state and the 'second-order election' as the characteristics of the European Parliament election, the findings implies that the Commission and the Council can be more vulnerable to the European Parliament's right to make and break the Commission as smaller portion of the MEPs belong to the first two groups.

\section{I . Introduction}

In parliamentary systems, parliaments hold the executive to account via two mechanisms from the start to then end: (1) investiture of the government, and (2) removal of the government (via a vote of censure or no-confidence). These are considerably blunter instruments than legislation, because the precise assignment of tasks and rules of discretion cannot be specified in detail in the process of investing or removing the executive. Nevertheless, when electing a government, the members of the parliamentary majority expect the executive to act in accordance with their preferences. If the executive acts in conflict with interests of the parliamentary majority, this would undermine political support amongst the electorate for the parliamentarians from the same political party(ies) as the government. In extreme cases, the parliamentary majority would initiate and support a vote of no-confidence in the executive. In other words, the power of investiture and removal may be 'blunt instruments', but they are nonetheless powerful mechanisms for parliamentary parties to control the behaviour of their executive.

In the European Union, the European Parliament has these instruments vis-à-vis the European Commission, the executive and bureaucratic organ of the Union. The atmosphere between the European Parliament and the European Commission has become in more conflicts for the last decade. Aiming for the further integration by means of strengthening the European Union vis-à-vis the member states, it has long been presumed, the two EU institutions have shared interests to work together. However, from the Treaty of Rome in 1957, the EP was assigned to control the Commission not the member states with the power of censuring it. Granted bigger legislative power through subsequent treaty reforms, the European Parliament has had less and less reasons to depend on the goodwill of the Commission to defend its policy preferences. Strengthening the European Parliament in the legislative arena was done in the erosion of the power of the Commission. To mark its assertiveness at the expense 
of the Commission, the European Parliament used its most blunt instruments to control the Commission, i.e. the powers of appointment and censure, in two events: the dramatic resignation of the Santer Commission in March 1999 and the reshuffle of the Barroso Commission in order to remove the Italian Commissioner candidate, Rocco Buttiglione as a result of pressure from the European Parliament in 2004. ${ }^{1 .}$ These events drew rare spotlight to the European Parliament in the eyes of the public while its power to approve a new Commission and its President has been used only three times and the European Parliament has never dismissed the Commission. ${ }^{2)}$

Such changing dynamic between the two EU institutions begs a question on the nature of their relationship and its driving forces. From the outset, the relationship is a hybrid model of government, with elements of separation-of-powers and elements of parliamentary government." First, the Commission is chosen by a special procedure. Since the Maastricht Treaty, the Commission is nominated by a unanimous agreement by the governments in the Council (which was changed to a qualified-majority in the Council by the Nice Treaty), and ratified by a simple majority in the European Parliament. Hence, the Commission is not strictly 'elected' by the majority in the European Parliament.

But, the process of choosing the Commission takes place immediately after each set of European elections (which are held every five years), and the majority that emerges from these elections possesses veto power on the choice of the governments. Hence, the outcome of European elections can influence the formation of the Commission. The Lisbon Treaty signed in 2007 makes this explicit by obliging the European Council to take "into account the elections of the European Parliament", and to have "held the appropriate consultation" when proposing a candidate for the Commission President. Also, it introduces a new rule to address the EP's rejection of the Commission President candidate by stating that the Council should propose a new candidate within a month if he/she fails to obtain support from a majority of the MEPs.

Second, the European Parliament has had the power to remove the Commission by a vote of censure. However, passing a vote of censure requires a so-called 'double-

1) Moury, Catherine, "Explaining the European Parliament's Right to Appoint and Invest the Commission," West European Politics 30-2 (2007).

2) The requirement for a motion of censure is stated in Article 201 in the Treaty of European Communities as consolidated by the Treaty of Amsterdam.

3) Kreppel, Amie and George Tsebelis, "Coalition Formation in the European Parliament," Comparative Political Studies 32 (1999), p.935; Marsh, Michael, "Testing the Second-Order Election Model after Four European Elections," British Journal of Political Science 28-4 (1998), p.593. 
majority' : a two-thirds majority of votes cast, which must constitute a majority of all Members of the European Parliament (MEPs, henceforth). This high threshold means that a large political majority needs to be constructed for a censure motion to be passed. Such a majority is unlikely to hold together for purely partisan-political reasons. As a result, in practice the censure power of the European Parliament is more akin to the right of the US Congress to impeach the US President for "high crimes and misdemeanours' than the power of a majority in a national parliament in Europe to withdraw its support for the government.

Third, the Commission does not have the power to dissolve the European Parliament. The European Parliament and the Commission both have a fixed term of five years. If the Commission is censured before the end of the Parliament's term, a new Commission is chosen until the Parliament's term is completed. However, such a design is not unique, as it exists in the Norwegian parliamentary system; where the term of the Storting is also fixed at five years, and the Norwegian cabinet cannot dissolve the Storting.

So, as in a parliamentary system, the European Parliament has a role in the appointment of the Commission and can sack the Commission. But, as in a separationof-powers system, there is no clear 'government' and 'opposition' cleavage in the European Parliament, ${ }^{4)}$ and legislative coalitions form on a case-by-case basis. This is because the term of Commission and the Parliament are fixed and censure of the Commission requires an oversized majority. Hence, the European Parliament is an interesting case for investigating how the 'blunt instruments' of executive appointment and removal operate.

In the recent literature, various approaches have addressed different questions. The theoretical work on the appointment of the Commission has focused on the impact of the rules for appointing the Commission on the Commission's possible composition and the possible sets of policy outcomes in the EU. ${ }^{5}$ The research on the actual operation of the appointment rules has treated MEP voting on the appointment of the Commission as a subset of MEP voting more generally. ${ }^{6}$ As a result, this research has tended to ignore

4) Neunreither, Karlheinz, "Governance without Opposition: The Case of the European Union," Government and Opposition 33-4 (1998), p.430.

5) Crombez, Christophe, "Policy Making and Commission Appointment in the European Union," Aussenwirtschaft 52-1/2 (1997); Crombez, Christophe and Simon Hix, "Unaccountable Brussels Bureaucrats? Implications of EU Constitutional Reforms on the Accountability of the Commission," Unpublished memo (2003); Hix, Simon, Abdul Noury and Gérard Roland, "How to Choose the European Executive: A Counterfactual Analysis, 1979-1999," in Charles Blankart and Dennis Mueller (eds), A Constitution of the European Union. (Cambridge, MA: MIT Press, 2004). 
the main function of the Parliament's right to approve the Commission and its President: as a device for support and control. Research on the motion of censure of the Santer Commission has paid some attention to the Parliament's power to make and break the Commission. ${ }^{7)}$ However, again, this research has focused on using these votes to investigate voting and coalitions inside the European Parliament, rather than trying to investigate the impact of these mechanisms on the independence of the Commission.

Also, thus far, no research has compared the behaviour of MEPs in the appointment of the Commission and the censure of the Commission. Appointment and censure are two sides of the same coin' ${ }^{8}$ ) A successful motion of censure necessitates replacing the current Commission with a new one. Similarly, the Parliament's failure to approve the nominated Commission is equivalent to keeping the present Commission in office.

Therefore, this article examines how the MEPs make decisions when using the Parliament's power of appointment and censure. Hypotheses are developed on MEPs' preferences on the control of the Commission. These are then tested on the voting behaviour of MEPs in the roll-call votes on the appointment of three Commissions, respectively headed by Jacques Santer, Romano Prodi and José Manuel Barroso, and the censure of the Santer Commission. By applying the same set of hypotheses to both appointment and censure, the similarities and differences in MEP behaviour in these votes are investigated. The next section first explains the rules for appointing and censuring the Commission.

6) Gabel, Matthew J. and Simon Hix, "The European Parliament and Executive Politics in the EU: Voting Behaviour and the Commission President Investiture Procedure. in Madeleine Hosli, Adrian Van Deemen and Mika Widgrén (eds), Institutional Challenges in the European Union (London: Routledge, 2002); Hix, Simon, "Executive Selection in the European Union: Does the Commission President Investiture Procedure Reduce the Democratic Deficit?," European Integration On-line Papers 1 (21). http://eiop.or.at/eiop/texte/1997-021a.htm. (1997),; Hix, Simon and Christopher Lord, "The Making of a President: The European Parliament and the Confirmation of Jacques Santer as President of the Commission," Government and Opposition 31-1 (1995).

7) Judge, David, and David Earnshaw, "The European Parliament and the Commission Crisis: A New Assertiveness," Governance 15-3 (2002); Ringe, Nils, "Government-Opposition Dynamics in Executive-Legislative Relations of the EU. The Santer Commission Resignation Crisis," European Journal of Political Research 44-5 (2005).

8) Magnette, Paul, "Appointing and Censuring the European Commission: The Adaptation of Parliamentary Institutions to the Community Context," European Law Journal 7-3 (2001). 


\section{The Rules for Electing and Censuring the Commission}

The procedure for appointing the College of Commissioners has changed through the revision of the Treaty. I focus on the rules under the Maastricht Treaty and the Amsterdam Treaty, however, as these were the rules in operation at the time of most of votes I analyse.

The investiture procedure begins with the nomination of a candidate for Commission President by unanimity in the European Council. ${ }^{9)}$ The Maastricht Treaty introduced the provision that the European Parliament is then 'consulted' on this nominee. The Amsterdam Treaty then replaced this consultation with a formal right of veto - by a simple majority of votes cast in the Parliament. Following approval of the Commission President by the European Parliament, the European Council, acting again by unanimity, nominates the rest of Commissioners. Under the Maastricht Treaty the Commission President needed to be consulted on the appointment of these other Commissioners, which was changed to a veto right by the Amsterdam Treaty.

Following the Maastricht Treaty, the European Parliament established an investiture procedure by subjecting the nominated Commissioners to hearings before the Parliament's committees. After the hearings, the Parliament votes by a simple majority whether to approve the Commission as a whole. In theory, this means that a Commission President who has been approved by the European Parliament cannot take office if the Commission as a whole is not approved by the Parliament.

However, the composition of the Commission is more or less fixed so that it is almost impossible for either European party groups or national parties in the European Parliament to influence government choices. The member state governments appoint their assigned numbers of Commissioners. ${ }^{10}$ The composition of the Commission is connected to the partisan composition of the governments because of the implicit norm of selecting Commissioners within the member states. Before the Barroso Commission, in the case of small states, who had only one Commissioner to select, the Commissioners were usually appointed from governing parties. The large member states - Germany, France, Italy, Spain and the UK - had two Commissioners. Spain, France and Britain

9) The Nice Treaty introduced a qualified-majority in the European Council for nominating the Commission President and the College of Commissioners.

10) The member states attempt to control policy direction of the Commission with their power to appoint "their" commissioner(s). For instance, Lord Cockfield was not reappointed to the second Delors Commission in 1989 because he had become "too European" for Margaret Thatcher. See Laursen, Finn, "The Role of the Commission," in Svein S. Andersen and Kjell A. Eliassen (eds), The European Union: How Democratic Is It? (London: Sage, 1996), p.121. 
usually chose one Commissioner from the governing parties and the other from the opposition, while Italy and Germany had appointed both Commissioners from the governing coalition partners. Since Barroso Commission, following the Nice Treaty, each member state appoints one commissioner, usually from the governing party.

In other words, the domestic political situation in each member state is the crucial factor for determining the partisan composition of the Commission. ${ }^{11}$ It is almost impossible for the European Parliament to decide which national parties will produce Commissioners. ${ }^{12)}$ As a result, there is little room for the transnational party groups in the Parliament, or the European Parliament as a whole, to control the policy preferences of the Commission. ${ }^{13)}$ For instance, when the EP vetoed the appointment of Buttiglione in 2004, the Italian government replaced him with Franco Frattini from the same party (i.e. Berlusconi's Forza Italia). The EP could change the person taking up the post of Commissioner but not the national party producing the personnel. When Frattini departed for the Berlusconi's new government as foreign minister in 2008, Antonio Tajani MEP, again from the same party, filled the seat.

Nevertheless, censure of the Commission is the Parliament's sole power. A motion of censure can be placed by at least one tenth of the component Members of Parliament. After the European Parliament President has forwarded the motion to the Commission, with the stated reasons for the motion, the European Parliament holds a debate. The motion of censure then requires a double-majority to be adopted: a two-thirds majority of the votes cast, which must represent a majority of the component members of the Parliament.

\section{Determinants of MEP Voting Behaviour in the Election/Censure of the Commission}

In this section I develop some hypotheses about how Members of the European Parliament can be expected to vote in the appointment and censure of the Commission.

11) For instance, on the composition of the vote on the Prodi's Commission, Prodi asked the German government to nominate one of its commissioners from the Right. But Schroder, the German chancellor, refused to do so and appointed one from his party and the other from the Greens, the coalition partner. (Financial Times, 1 July 1999)

12) Although the EPP insisted that the Prodi's Commission should reflect the result of 1999 European election, the appointed Commission had more socialists than people from right despite the swing to right at the election.

13) Franchino, Fabio, "Control of the Commission's Executive Functions: Uncertainty, Control and Decision Rules," European Union Politics 1-1 (2000), p.67. 
My key contention is that MEP behaviour in these votes is ultimately determined by MEP policy preferences. When deciding how to vote, each MEP makes a judgement about the extent to which the Commission's policy preferences are likely to be close from his/her preferences.

The common assumption of spatial models of parliamentary government formation is that legislators vote for the cabinet if the government is likely to lead to policy outcomes closer to the legislator's ideal position than the status quo of the previous government. ${ }^{14)}$ Adapting this to the context of the European Parliament, MEP's voting decisions on the appointment of the Commission and its President depends on whether the policy difference between the MEP and the current Commission is less than between the MEP and the nominated one. Crombez (1997) makes a similar argument about the motivation of governments when deciding on the formation of the Commission.

Similarly, based on the theory of government survival and termination, one may suspect that MEPs decisions on the censure of the Commission depends on whether the current Commission has closer ideal policy positions than the position of the Commission that would be expected to replace it. Franchino (2000), inter alia, argues that the procedure for motion of censure is similar to the presidential impeachment in the US rather than to a parliamentary vote of no confidence because the threshold for successful censure requiring the combination of two-thirds majority of votes cast and absolute majority of members is higher than those in the parliamentary system. Regardless of the voting threshold, however, the basic matter for the MEPs to consider is same as the parliamentarians: a new executive body should replace the censured one. ${ }^{15}$ ) This requires comparison between the current government's policies and those of the prospective one would pursue.

14) E.g. Laver, Michael, and Kenneth Shepsle, Making and Breaking Governments (Cambridge: Cambridge University Press, 1996); Laver, Michael, and Kenneth Shepsle, "Ministrables and Government Formation: Munchkins, Players and Big Beasts of the Jungle," Journal of Theoretical Politics 12-1 (2000); Schofield, Norman, "Political Competition and Multiparty Coalition Government," European Journal of Political Research 23-1 (1993); Bergman, Torbjorn, "Formation rules and minority government," European Journal of Political Research 23-1 (1993); Crombez, Christophe, "Legislative Procedures in the European Community," British Journal of Political Science 26-2 (1996); Baron, David, "Government Formation and Endogenous Parties," American Political Science Review 87- 1 (1993); Warwick, Paul, "Ministerial Autonomy or Ministerial Accommodation? Contested Bases of Government Survival in Parliamentary Democracies," British Journal of Political Science 29 (1999).

15) Huber, John, "The Impact of Confidence Votes on Legislative Politics in Parliamentary Systems," American Political Science Review 90-2 (1996). Diermeier, Daniel and Timothy J. Feddersen, "Cohesion in Legislatures and the Vote of Confidence Procedure," American Political Science Review 92-4 (1998). Baron, David, "Comparative Dynamics of Parliamentary Governments," American Political Science Review 92-3 (1998). 
However, the weak power of the European Parliament in the appointment of the Commission suggests that this hypothesis may not hold for MEPs as strongly as it does for legislators in domestic parliaments in Europe. The EP cannot determine the composition of the Commission alone. Under such circumstances, the MEPs cannot guess the composition of alternative nominees of the Commission. Consequently, it is difficult for them to consider whether the position of the nominated Commission would be closer to them than the newly nominated one. Similarly, in a censure vote, it is difficult for MEPs to precisely predict whether the new Commission would have more policy interest compatibility than the current one with them.

MEPs can make some judgements about the likely policy preferences of re-nominated Commissioners or of the likely make-up of a new Commission after a censure vote. As discussed, member states with one Commission almost always nominate their Commissioner from one of the governing parties, and member states two Commissioners usually nominate one from a governing party and the other from the main opposition party (although there are some exceptions, as with Germany in 1999).

But, even if the MEPs are sure that the censure of the Commission would bring the Commission closer to their ideal policy positions, they would have to wait a long time. Because it takes time for a new Commission to be appointed and take office following a censure vote, the incumbent Commission stays in office as a caretaker administration for a considerable time. Therefore, the policy position of alternative Commissions may not influence MEPs' voting decisions as strongly as in a classic system of parliamentary government.

Thus, the first hypothesis is as follows:

Hypothesis 1: The closer the distance between the ideal policy preference of an MEP and the Commission/Commission President is, the more likely the MEP will vote for the appointment of the Commission or Commission President, and against the censure of the Commission.

This is a moderate adoption of the "making and breaking" government literature, taking into account the weak power of the EP to determine the composition of the Commission. Rather than arguing that the MEPs vote to make or break the Commission, I maintain that they vote to express their political support/objections for/to the Commission, expecting more strongly supported Commission to pursue its policy preferences more actively. The more the MEPs favour the Commission's policy 
preferences, the more policy benefits they gain from its activism. Stronger Commission is more salient for the MEPs who share policy interests with it.

Second, the results of the votes on the appointment and censure of the Commission have positive or negative impacts on the general process of European integration. If a Commission is appointed, it can get on with the job of preparing a policy agenda and proposing legislation. In contrast, if a nominated Commission President or Commission is blocked by the European Parliament, or if the European Parliament censures a Commission, EU business will come to a standstill until the 'crisis' is resolved. ${ }^{16)}$ In this situation, the anti-European media will have a 'field day': pointing a finger at incompetent or corrupt government in Brussels. This suggests that MEPs' preferences on European integration might also influence how they vote in appointment and censure motions.

Thus, the second hypothesis is as follows:

Hypothesis 2: The more an MEP supports European integration the more likelihood the MEP will vote for approving the nominees for the Commission President or the College of the Commission, and against the censure of the Commission.

A proxy for the preferences of the Commission is the party-political make-up of the Commission. First, MEPs can assume that the partisan composition of the Commission, in terms of the overall balance of Social Democrats, Conservatives, Liberals and Greens, will influence the direction of the policy agenda the Commission can pursue. Second, if an MEP is from the same national party as a Commissioner, then the MEP can assume that his/her preferences are very close to at least one member of the Commission. National parties also provide channels of communication and information between Commissioners and MEPs.

Thus, the third hypothesis is as follows:

Hypothesis 3: If the Commission includes a Commissioner from the same national party as an MEP (or if the Commission President is from the same national party as an MEP), the MEP will be more likely to vote for approval of the Commission (Commission President) and less likely to vote against the censure of the Commission.

16) In fact the Santer declared that the Commission would not take any new political initiative after its resignation. (The European Parliament, 22 March 1999) 
Fourth, the votes on the approval of the Commission and its President and on the censure of the Commission are of particular saliency for the member states governments. As Hix and Lord (1995) and Gabel and Hix (2002) point out, the parties in government have vested interest for the vote on approval to be passed by the European Parliament because they nominated the candidates. Having been through negotiation on who should be nominated, the nominee for the Commission President is considered to be the common candidate of the governments. Also, the choice of the Commission President is often part of a private log-roll package between several of the governments; whereby one member states gains the Commission President in return for another member state gaining another key public office (such as the President of the European Central Bank, the Secretary-General of the Council, or the President of the International Monetary Fund).

Unlike the choice of the President, the member states do not interfere in each other's choice of Commissioners. But, the choice of the rest of the College of the Commission is also the result of careful intra-party and intra-coalition negotiations in each member state. The choice of a particular party figure for a Commission is often at the expense of other possible candidates, who have to be appeased in some other way. Also, where coalition governments are concerned, the choice of one or both Commissioners is usually the result of a particular deal between the coalition partners. Thus, if the European Parliament fails to approve the nomination by the member state government, the cost for the re-nomination is potentially enormous.

Hence, the governments that are part of the package-deal that produces the nominee for Commission President and the nominations for the other members of the Commission are eager not to see these deals unravelled by a rejection of the Commission President or the Commission as a whole by the EP.

In censure votes, governments (as represented in the Council or European Council) do not have to announce their positions before the vote in the Parliament. There is no formal phase in the process when the national governments collectively or individually are required to take positions on the issue. Censuring the Commission is the Parliament's sole right. Unless they have other national or partisan interests to protect, the governing parties are less likely to put pressure on their MEPs to support their positions in censure votes than in appointment votes.

But, governments can, and usually do, express their views to their MEPs on censure votes. And, parties in government who have members of the Commission are likely to be against a motion of censure. If the European Parliament succeeds in adopting the motion of censure and consequently sacking the entire College of Commissioners, the member states need to spend time and resources to select a new Commission. To avoid 
such costs, the MEPs from governing parties are likely to be under pressure to vote against the censure of the Commission.

Hence, the fourth hypothesis is as follows:

Hypothesis 4: If an MEP is from a national governing party, the MEP will be more likely to vote for the approval of the Commission and the Commission President, and more likely to vote against the censure of the Commission.

Finally, the general literature on the termination of governments suggests that legislators with rational expectations will respond to changes in the political environments, and so vote to remove a government when the political conditions exist that would mean that the new administration would be closer to the preferences of the legislative majority than the current administration. ${ }^{17)}$ In the EU context, when the Commission is originally formed it broadly represents the political make-up of the Council at the time of its investiture, for the reasons discussed. However, because there are different electoral timetables in each member state, the political make-up of the Council changes as governments lose elections and are replaced by new parties and new coalitions.

Also, the significance of gaining or losing the Commissioners can be reduced by the time when the vote of censure was conducted. One school of hazard rate approach in the study of cabinet termination argues that cabinets are more likely to terminate the longer they are in office. ${ }^{18)}$ Laver and Shepsle (1998: 32) also pointed out that the opportunity costs of a government collapse declines as any administration approaches the end of its constitutionally imposed maximum term. By the same token, it is arguable that the opportunity costs of losing a commissioner declines as the present Commission approaches the end of its maximum term imposed by the Treaties. If accepting this argument, the national parties and transnational party groups lose the incentive to back their commissioners as the term of the Commission approaches the end.

This cannot be tested with the cases of censure votes on the Commission since there was only one incident where the European Parliament credibly threatened to sack the Commission. But, it is nonetheless worth considering in the case of the EU. Sacking the Commission as a whole might produce gains or losses for party groups' or national

17) Grofman, Bernard, and Peter Van Roozendaal, "Toward a theoretical explanation of premature cabinet termination," European Journal of Political Research 26-1 (1994). Laver and Shepsle. (1996)

18) Diermeier, Daniel, and Randy T. Stevenson, "Cabinet Survival and Competing Risks," American Journal of Political Science, 43-4 (1999). 
parties' own commissioners. Because of the implicit norms for selecting the Commissioners in each member state, the MEPs can predict which parties the new commissioners will belong to. If the number of Commissioners of a party group increases, the MEPs of that party group have incentive to vote for the censure. If the number of its Commissioners in a new Commission is smaller than that in the present Commission, party groups or national parties might have incentives to oppose the censure motion in order to secure its Commissioners.

For example, when the Prodi Commission was elected in July-November 1999, the overwhelming centre-left majority in the Council was reflected in the make-up of the Commission, where over 50 percent of the Commissioners came from Socialist or Green parties. After the June 1999 European elections, the European People's Party (EPP) emerged as the largest party in the European Parliament, and with the potential of forming a centre-right majority with the Liberals and the MEPs from the various groups and national parties to the right of the EPP. However, by early 2001, the centreleft majority in the Council had been replaced by a centre-right majority, in the wake of a series of election defeats by the centre-left (in France, Italy, Austria, Netherlands, Denmark, and Portugal).

In a normal parliamentary democracy, in this new political environment, the centreright majority in the European Parliament would have been tempted to sack the Prodi Commission, in the knowledge that the new Commission would be composed predominantly of centre-right politicians (chosen by the centre-right majority in the Council) and so would be much closer to the policy preferences of the majority in the Parliament than the Prodi Commission.

This, of course, did not happen. This might be because the centre-right in the European Parliament expected that when the Prodi Commission came to the end of its term, the next Commission would be more centrist anyway. Hence, there was little to gain from removing the Commission early.

More fundamentally, though, another reason for not sacking a Commission is the double-majority voting threshold for passing a vote of censure. To secure a two-thirds majority in a censure vote, the two largest parties in the Parliament-the EPP and Party of European Socialists (PES) - would have to vote together. As the new Commission would be considerably to the right of the Prodi Commission, the PES had every incentive to see the current Commission last until the end of its term. This consequently illustrates how the high voting threshold for censuring the Commission means that it is almost impossible for the European Parliament to remove the Commission for purely party-preference reasons. In contrast, the Parliament effectively 
censured the Santer Commission in March 1999 (the Commission resigned before a third censure vote could be taken, which they were likely to lose) as a result of allegations of mismanagement and incompetence, which enabled a cross-party coalition to form against the Commission. In the case of the Santer Commission, all the main parties expected to gain from removing the Santer Commission and replacing it with a more legitimate and credible administration, regardless of the likely political make-up of the new Commission.

\section{Statistical Analysis}

\section{Seven Votes on the Santer, Predi and Barrosø Commissions}

Since the Maastricht Treaty, the European Parliament has taken a total of eleven votes on the appointment of the Commission and Commission Presidents and the censure of the Commission. This article focuses on seven of these votes, the results of which are shown in Table 1. The first two votes were on the approval of Jacques Santer as Commission President and the approval of the Santer Commission as a whole, respectively ${ }^{19)}$ These were the first votes on the Commission President to be taken under the rules of the Maastricht Treaty, where the European Parliament had a right to be consulted on the choice of the Commission President.

The third vote was on a motion of censure in 1997 in reaction to the Commission' s handling of the so-called 'BSE crisis'. The fourth vote was a censure motion on 14 January 1999, in the wake of allegations against mismanagement in the Commission. While the Santer Commission survived this vote, it finally resigned in March 1999 in the shadow of a follow censure vote it expected to lose. ${ }^{20)}$

The fifth vote was on the appointment of Prodi as Commission President. For the first time, The European Parliament voted under the new procedure introduced by the Amsterdam Treaty, which gave it a formal right of veto of the governments' nominee for Commission President. Following the June 1999 European elections, the new Parliament voted to approve Prodi as the Commission President and the Commission as a whole for the remainder of the Commission's 1995-1999 term as well as for the new

19) The process from the nomination of Santer by the European Council to the vote on his confirmation is described in Hix and Lord (1995), pp.64-75.

20) For the explanation of the events from tabling the motion of censure to the resignation of the Commission led by Santer, see Judge and Earnshaw (2002) and Ringe (2005). 
Table 1. Investiture and Censure Votes Between 1994 and 2004

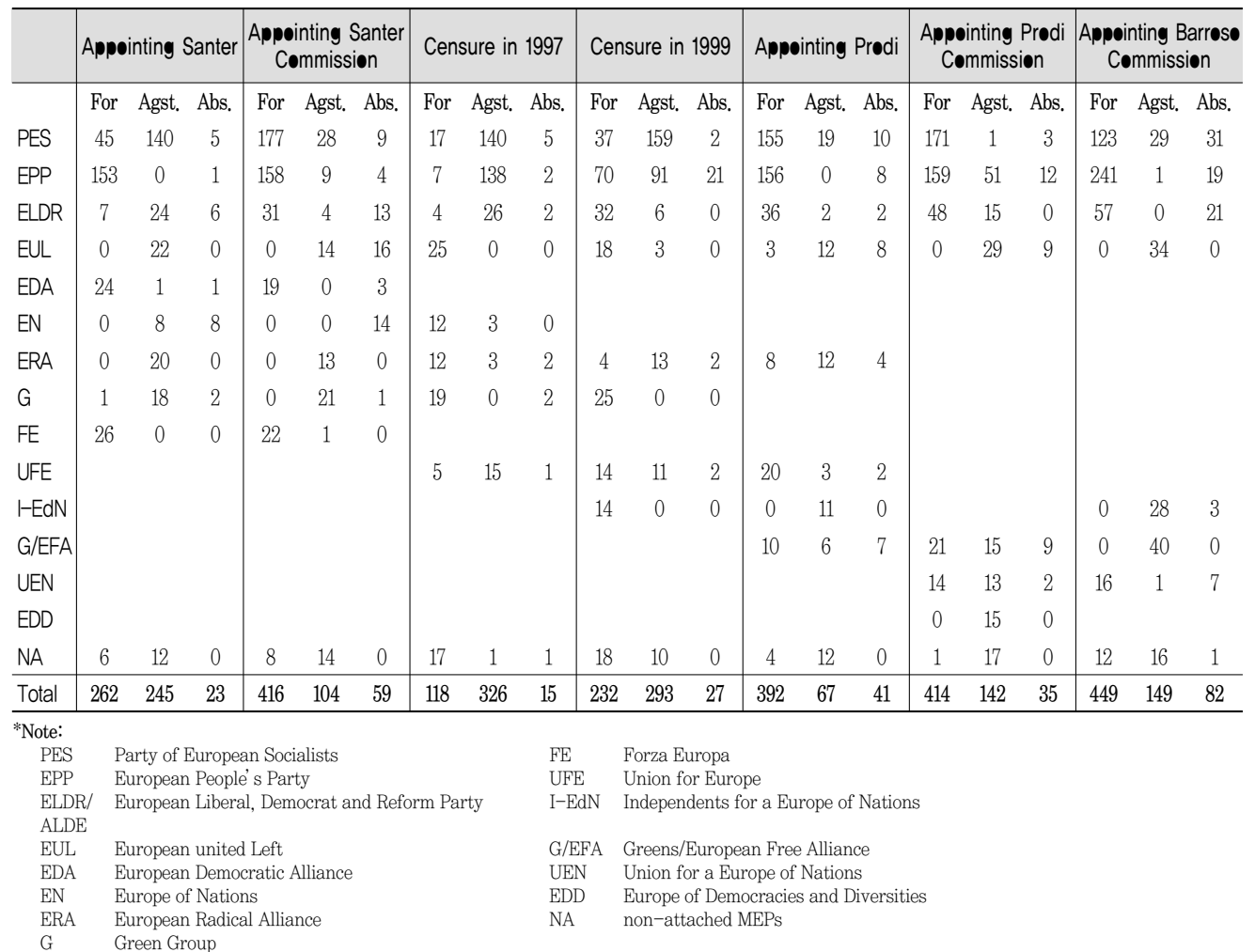

2000-2004 term. After taking four votes to approve the Commission and its President separately for two separate terms, the European Parliament took another vote on all these actions as a whole. The vote covering all the actions instead of all the separate votes on the Prodi Commission is used, as the behaviour of the MEPs in all these votes is almost identical. ${ }^{21}$

Finally, the seventh and last vote was on the appointment of the Barroso Commission taken under the Treaty of Nice. Then the EP changed its Rules of Procedure, making the vote on the Commission President secret ballot but left the one on the Commission as a whole roll call vote.

21) In fact, the various results of the other four votes on September 1999 reflect the opinions of some transnational party groups and some national groups about the Prodi's Commission and the process for its appointment. The form of interim Commission for the remained term of Commission 1995-2000 was a controversial issue. Some parties also expressed their dissatisfaction about some commissioners by voting against the approval of the Commission despite their support for the text as a whole. For more details about their positions, see European Parliament (14 September 1999) "The new Commission approved," The Week, http://www.europarl.eu.int/dg3/sdp/pointses/en/1999/index.htm. 


\section{The Variables}

The above hypotheses on MEP behaviour in these seven votes are tested by using logistic regression. The dependent variable in each model is how each MEP voted in each vote. The variable takes the value 1 if an MEP voted Yes, and the value 0 if an MEP voted No and voted to abstain.

There are four types of independent variables in the analysis. First, three variables are used to test the impact of policy differences between the Commission and the MEPs on MEP voting behaviour vis-à-vis the Commission. I use two different measures of a priori policy preferences of MEPs and Commission. The first two variables, on the "leftright' and 'EU integration' distance between the MEPs and Commission, are constructed using data on national party positions on these two policy dimensions in the Manifestos Research Group dataset. ${ }^{22)}$ The third variable is constructed from individual MEP NOMINATE scores; which are the 'revealed' ideal point estimates of MEPs on the two dimensions produced by the application of the NOMINATE scaling method to all roll-call votes in the European Parliament in the 1994-1999 and 1999-2001 periods. ${ }^{23}$ These NOMINATE scores correlate with the Manifestos Research Group measures data for left-right and EU integration.

Constructing these variables it is necessary to measure the positions of each MEP, the position of the Commission as whole, and comparing these two positions. I start with the national party positions that are estimated by the Manifesto Research Group (MRG). I assume that each MEP has the same score as his/her national party. The left-right variable is taken from the amalgamated left-right variable in the MRG dataset, and the 'support for EU integration' variable is calculated from the European Community scale in the MRG data. To calculate the position of the Commission I start by assuming that each Commission has the same policy position as his/her national party. Because the Commission decides by a majority vote, it is assumed that the position of the Commission as a whole is the median position of all the Commissioners on a given dimension. With an even number of Commissioners, the Commission's position is calculated as the mid-point between the 10th and 11th Commissioner. Crombez and Hix (2003) use the same method. Then the 'policy distance' between each MEP and the

22) Budge, Ian et al., Mapping Policy Preferences: Estimates for Parties, Electors and Governments 1945-1998 (Oxford: Oxford University Press, 2001); Budge, Ian et al., Mapping Policy Preferences: Estimates for Parties, Electors, and Governments in Eastern Europe, European Union, and OECD 1990-2004 (Oxford: Oxford University Press, 2006).

23) Hix, Simon, Abdul Noury and Gérard Roland, Democratic Politics in the European Parliament (Cambridge: Cambridge University Press, 2007). 
Commission is calculated by taking the absolute difference between the MEPs score and the Commission's score.

In addition, to address the possible problem of giving the same score to the MEPs from same national parties, I use the individual MEP scores on the two first dimensions produced by applying the NOMINATE scaling method to the roll-call votes. For the Commission, it is assumed that each Commissioner has the same position as the mean position of the MEPs from his/her national party. I then calculate the position of the Commission as a whole as the two-dimensional median, in the same was as I did with the MRG data. I calculate the distance between each MEP and the Commission as the two-dimensional Euclidean distance between the MEP's two-dimensional location and the two-dimensional location of the Commission.

One problem, however, was that in the 1994-1999 Commission there was a German FDP Commissioner, but no FDP MEPs. As a result, a NOMINATE position for the Commission as a whole could not be calculated in this period. Hence, the NOMINATE variable is only included in separate models on the appointment of Santer as President, where I calculate the position of each MEP relative to the NOMINATE score of Jacques Santer's political party (the Luxembourg Christian Democrats), and in the votes on the Prodi Commission. Also, the NOMINATE score for the 2004-2009 EP is not available at the time of writing this article. I use only the MRG scores for the analysis of the vote on Barroso Commission.

Second, the fourth variable, 'Left-Right Position', is a control variable which measures the impact of ideology within the European Parliament. This aims to reflect the existing study of EP roll call votes. I include this variable, the position of MEPs on the left-right dimension of the MRG data. Extant research demonstrates the dominance of the leftright ideological cleavage in the EP roll call votes. I give the value of a national party to its MEPs. Whenever I use the MRG data, I adopt the scales produced from the most recent national elections for each country.

Third, to measure the impact of MEP' general preference for European integration on support or opposition to the Commission I include a general variable that measures MEPs' attitudes towards European integration. The variable 'support for EU integration' is calculated from European Community scale in the MRG data in this way for Hypothesis 2.

Fourth, I include two variables that measure the party-political connections between MEPs, the governments in the Council and the Commission. The first of these variables, 'National Party in the Commission', takes the value 1 of an MEP's national party has a Commission and 0 otherwise. The second variable, 'National Party in the Council', 
takes the value 1 of an MEP's national party is in government (and hence sits in the EU Council) and 0 otherwise.

Table 2. Logit regression on the roll call votes of the MEPs on the Santer Commission

\begin{tabular}{|c|c|c|c|c|c|c|c|}
\hline \multirow[b]{2}{*}{ Item of vote (date): } & \multicolumn{4}{|c|}{ Appointment } & \multicolumn{3}{|c|}{ Censure } \\
\hline & H & Santer & p. 1994) & $\begin{array}{c}\text { Santer Commission } \\
\text { (Jan. 1995) }\end{array}$ & $\mathrm{H}$ & $\begin{array}{l}\text { Santer Commissio } \\
\text { (June 1997) }\end{array}$ & $\begin{array}{l}\text { Santer Commission } \\
\text { (Jan. 1999) }\end{array}$ \\
\hline Independent variable & & Model 1 Coef. & Model 2 Coef. & Model 3 Coef. & & Model 4 Coef. & Model 5 Coef. \\
\hline Policy Difference-Left-Right & - & $\begin{array}{c}-.07^{*} \\
(.03)\end{array}$ & & $\begin{array}{l}-.00 \\
(0.01)\end{array}$ & + & $\begin{array}{l}-.01 \\
(.02)\end{array}$ & $\begin{array}{c}-.03^{* *} \\
(.01)\end{array}$ \\
\hline Policy Difference-EU Integration & - & $\begin{array}{l}-.01 \\
(.07)\end{array}$ & & $\begin{array}{l}-.56^{* * * *} \\
(.09)\end{array}$ & + & $\begin{array}{c}1.06^{* * *} \\
(.14)\end{array}$ & $\begin{array}{l}.40^{* * * *} \\
(.06)\end{array}$ \\
\hline Policy Difference-NOMINATE & - & & $\begin{array}{c}-6.26^{* * *} \\
\quad(73)\end{array}$ & & & & \\
\hline Left-Right Position & & $\begin{array}{l}.08^{* *} \\
(.03)\end{array}$ & $\begin{array}{l}-.00 \\
(.00)\end{array}$ & $\begin{array}{l}.01 \\
(.01)\end{array}$ & & $\begin{array}{l}-.04^{* *} \\
(.03)\end{array}$ & $\begin{array}{l}.02^{* * * *} \\
(.00)\end{array}$ \\
\hline MEP Support for EU Integration & + & $\begin{array}{l}.01 \\
(.06)\end{array}$ & $\begin{array}{l}-.24^{* *} \\
(.07)\end{array}$ & $\begin{array}{l}.18^{* * * *} \\
(.05)\end{array}$ & - & $\begin{array}{l}-.38^{* * * *} \\
(.07)\end{array}$ & $\begin{array}{l}.00 \\
(.03)\end{array}$ \\
\hline National Party in the Commission & + & $\begin{array}{l}.19 \\
(.23)\end{array}$ & $\begin{array}{c}1.16^{* * *} \\
(.36)\end{array}$ & $\begin{array}{l}.45 \\
(.29)\end{array}$ & - & $\begin{array}{l}-2.53^{* * * *} \\
(.49)\end{array}$ & $\begin{array}{l}-1.29^{* * * *} \\
\quad(.24)\end{array}$ \\
\hline National Party in the Council & + & $\begin{array}{c}2.57^{* * * *} \\
(.26) \\
\end{array}$ & $\begin{array}{c}2.08^{* * * *} \\
(.32) \\
\end{array}$ & $\begin{array}{c}1.24^{* * *} \\
(.32) \\
\end{array}$ & - & $\begin{array}{l}-.31 \\
(.43) \\
\end{array}$ & $\begin{array}{c}-1.09^{* * * *} \\
(.24) \\
\end{array}$ \\
\hline $\begin{array}{l}\text { Log likelihood } \\
x^{2}(7)^{*}\left(\text { prob }>x^{2}\right) \\
\text { Pseudo R2 } \\
\text { No. of obs }\end{array}$ & & $\begin{array}{c}-237.89 \\
155.27(.00) \\
.24 \\
458\end{array}$ & $\begin{array}{c}-137.63 \\
343.20(.00) \\
0.55 \\
448\end{array}$ & $\begin{array}{c}-178.05 \\
115.46(.00) \\
.24 \\
493\end{array}$ & & $\begin{array}{c}-110.25 \\
184.22(.00) \\
.45 \\
392\end{array}$ & $\begin{array}{c}-244.86 \\
165.15(.00) \\
.25 \\
481\end{array}$ \\
\hline
\end{tabular}

\section{Results}

Tables 2 and 3 show the results, where the columns headed with 'H' denote the expected sign of the beta coefficient in each model.

The results can be summarised as follows. First, Hypothesis 1 is confirmed: the policy difference between an MEP and the Commission negatively influences her support for the Commission. The policy difference on the left-right, as measured for each national party's group of MEPs, does not seem to be significant in all models. However, the significance of policy distance between MEPs and the Commission as measured by NOMINATE scores, does suggest that socio-economic policy concerns influence how MEPs behave vis-à-vis the Commission. Also, the policy distance on the EU integration dimension is significant and in the hypothesised direction in all models except model 1 (on the appointment of Santer as Commission President).

The results suggest that giving the same values to the MEPs from the same national parties (using the Manifestos Research Group data) does not seriously distort the analysis. Increasing policy conflicts between the Commission and the MEPs induces 
Table 3. Logit regression on the roll call votes of the MEPs on Prodi Commission and Barroso Commission

\begin{tabular}{|c|c|c|c|c|c|c|}
\hline \multirow[t]{2}{*}{ Item of vote (date): } & \multirow[t]{2}{*}{ H } & \multicolumn{2}{|c|}{$\begin{array}{c}\text { Appointment of Prodi } \\
\text { (May 1999) }\end{array}$} & \multicolumn{2}{|c|}{$\begin{array}{l}\text { Appointment of Prodi Commission } \\
\text { (Sep. 1999) }\end{array}$} & \multirow{2}{*}{$\begin{array}{c}\text { Appointment of } \\
\text { Barroso Commission } \\
\text { (Nov. 2004) } \\
\text { Model } 10 \text { Coef. }\end{array}$} \\
\hline & & Model 6 Coef. & Model 7 Coef. & Model 8 Coef. & Model 9 Coef. & \\
\hline Policy Difference-Left-Right & - & $\begin{array}{l}-.01 \\
(.02)\end{array}$ & & $\begin{array}{l}-.01 \\
(.01)\end{array}$ & & $\begin{array}{c}-.04^{* *} \\
(.01)\end{array}$ \\
\hline Policy Difference-EU Integration & - & $\begin{array}{l}-.43^{* * *} \\
(.09)\end{array}$ & & $\begin{array}{l}-.74^{* * * *} \\
(.08)\end{array}$ & & $\begin{array}{l}-.33^{* * *} \\
(.06)\end{array}$ \\
\hline Policy Difference-NOMINATE & - & & $\begin{array}{l}-1.21^{* *} \\
(.41)\end{array}$ & & $\begin{array}{l}-9.25^{* * * *} \\
(1.04)\end{array}$ & \\
\hline Left-Right Position & & $\begin{array}{l}.01 \\
(.00)\end{array}$ & $\begin{array}{l}.01 \\
(.00)\end{array}$ & $\begin{array}{l}.01 \\
(.00)\end{array}$ & $\begin{array}{l}.00 \\
(.00)\end{array}$ & $\begin{array}{c}.08^{* * * *} \\
(.00)\end{array}$ \\
\hline MEP Support for EU Integration & + & $\begin{array}{c}.37 * * * \\
(.07)\end{array}$ & $\begin{array}{l}.32^{* * * *} \\
(.07)\end{array}$ & $\begin{array}{l}.41^{* * * *} \\
(.05)\end{array}$ & $\begin{array}{l}.05 \\
(.04)\end{array}$ & $\begin{array}{l}.08^{*} \\
(.03)\end{array}$ \\
\hline National Party in the Commission & + & $\begin{array}{l}-.37 \\
(.39)\end{array}$ & $\begin{array}{l}-.50 \\
(.46)\end{array}$ & $\begin{array}{c}1.31 * * * \\
(.32)\end{array}$ & $\begin{array}{l}2.16^{* * *} \\
(.38)\end{array}$ & \\
\hline National Party in the Council & + & $\begin{array}{l}.28 \\
(.41)\end{array}$ & $\begin{array}{l}-.24 \\
(.44) \\
\end{array}$ & $\begin{array}{c}1.39^{* * *} \\
(.39) \\
\end{array}$ & $\begin{array}{l}-.37 \\
(.36) \\
\end{array}$ & $\begin{array}{c}2.03^{* * * *} \\
(.28)\end{array}$ \\
\hline $\begin{array}{l}\text { Log likelihood } \\
x^{2}(7)^{*}\left(\text { prob }>x^{2}\right) \\
\text { Pseudo R2 } \\
\text { No. of obs }\end{array}$ & & $\begin{array}{c}-117.63 \\
85.62(.00) \\
.26 \\
415\end{array}$ & $\begin{array}{c}-88.94 \\
47.52(.00) \\
0.21 \\
340\end{array}$ & $\begin{array}{c}-185.2396 \\
225.35(.00) \\
.3782 \\
524\end{array}$ & $\begin{array}{c}-164.3678 \\
259.27(.00) \\
.4409 \\
518\end{array}$ & $\begin{array}{c}-272.806 \\
235.57(.00) \\
.3016 \\
620\end{array}$ \\
\hline
\end{tabular}

MEPs to vote against the appointment and for censure of the Commission. But, because left-right distance are not always significant, whereas EU integration and the generic NOMINATE policy scale are significant, it is impossible to say which policy dimension prevails in conflicts between the Commission and the European Parliament.

Second, more pro-EU integration MEPs are less likely to provoke a constitutional crisis in the EU, and so tend to vote for the proposed Commission President and against the censure of the Commission. Except for the vote on the appointment of Santer and the censure of his Commission in 1999, Hypothesis 2 is confirmed. Interestingly, in the vote on the appointment of the Santer Commission, pro-integration MEPs tended to vote against the appointment. This can be explained by the MEPs' resentment at the selection of Santer as the lowest-common-denominator candidate by the member states, as opposed to the more integrationist candidates Jean-Luc Dehaene or Wim Kok. $^{24)}$ By expressing their dissatisfaction at the appointment process, the MEPs may also have been eager to establish more influence for themselves in the subsequent selection of the rest of the College of Commissioners. Hence, integrationist MEPs expressed support for the stronger European Parliament by voting against his appointment.

Third, partisan links between MEPs and the Commission also make a difference, as

24) Hix and Lord (1995). 
Hypothesis 3 predicts. In the vote on Barroso Commission, the variable is dropped from the analysis for perfectly predicting the voting the MEPs' behaviour. When their national partisans in the Commission are under threat-for example, in the two votes on the motion of censure-MEPs tried not to lose them. This is in line with other research, which has shown that MEPs are eager to defend 'their' Commissioners if they are the target of criticism. ${ }^{25)}$

However, the effect of national party representation in the Commission was not consistent across all votes. It had an effect in the appointment of Santer as Commission President, in the two votes on the censure of the Santer Commission, and in the appointment of the Prodi Commission. But, national party representation did not have an effect in the votes on the appointment of the Santer Commission or the appointment of Prodi as Commission President. In other words, when Santer was to be approved as the nominee for Commission President in July 1994, the possibility of having a Commissioner from their national parties in the incoming Commission induced the MEPs to vote for Santer. But, once the individual Commissioners had been nominated, and the political make-up of the Commission was now clear, it did not affect their voting decisions. But, the reverse was true in the case of the Prodi Commission: where MEPs were not driven by national party interests in the appointment of Prodi as President in May 1999, but were driven by national party interests in the appointment of the Commission as a whole in September 1999.

Fourth, however, MEPs are also influenced by domestic government/opposition dynamics, as Hypothesis 4 suggests. Government/opposition dynamics were significant in all five appointment votes: where MEPs from governing parties were more likely to vote for the governments' nominee for Commission President or nominees for the Commission as a whole, than MEPs from opposition parties. Also, government/ opposition dynamics were significant in the second censure vote on the Santer Commission, in January 1999, where MEPs from governing parties were more likely to vote against the censure of the Commission. But, these interests were not significant in the first censure vote on the Santer Commission, in June 1997. As discussed, this suggests that governing parties' interests are clearer in appointment votes than in censure votes, as their positions are 'on the record' in the former but not the later. However, when there is a lot at stake in a censure vote (i.e. the vote may pass), as was the case in January 1999, governing parties are likely to be opposed to the censure of the Commission, either to protect their members in the Commission, or to prevent an

25) Judge and Earnshaw (2002); Ringe (2005). 
institutional crisis developing.

The issues linked to these two censure votes can explain the different interests of governing parties. The censure vote in 1997 was triggered by the so-called 'BSE crisis', where the European Parliament mainly criticised the previous Commission, headed by Jacques Delors, and the United Kingdom. Although the European Parliament also criticised the Council, the Council did not publicly take sides with the Commission in the series of events leading to the motion of censure. The censure in 1999 concerned the management of the EU budget by the Commission. When the European Parliament examined the Commission's management of the EU budget through the annual budgetary discharge process in 1998, the Council, the involvement of which was required by the treaty, recommended the European Parliament to grant the discharge and consequently supported the Commission. The European Parliament rejected the discharge of the budget and subsequently voted on the motion of censure. As repeated rejection of granting the discharge was known to lead to the motion of censure, the Council implicitly objected to censuring the Commission in 1999.

Finally, the control variable of the MEPs' position on left-right ideology is mainly significant in the censure votes. When MEPs voted on the appointment of the Commission as a whole, their left-right location did not make a difference. Because the main party groups on the left and the right, the PES and EPP respectively, had interests in getting their Commissioners approved, the left-right ideological cleavage was not profound. When Prodi was voted as the nominee for the Commission President, the urgent need for stability in the EU after the dramatic resignation of the Santer Commission made the MEPs support him.

But, there was a left-right split in the Parliament in the vote in July 1994 on the appointment of Santer as Commission President and on the appointment of Barroso Commission. As Santer belonged to the centre-right, the MEPs from the EPP and the other party groups on the right were most eager to support him. The support of these MEPs continued until his Commission was put to a motion of censure in 1997. Again, the MEPs on the right were more inclined to vote against censure than the MEPs on the left. However, the position switched in January 1999, with the right now more inclined to vote for censure than the left. This time, the main targets of the Parliament's criticism were two Socialist Commissioners, Edith Cresson and Manuel Marin. 
Table 4. Predicted probabilities of MEPs' support for the Commission

\begin{tabular}{|c|c|c|c|c|c|c|c|}
\hline Item of vote (date): & $\begin{array}{c}\text { Appointment of } \\
\text { Santer } \\
\text { (Sep. 1994) }\end{array}$ & $\begin{array}{l}\text { Appointment of } \\
\text { Santer } \\
\text { Commission } \\
\text { (Jan. 1995) } \\
\end{array}$ & $\begin{array}{c}\text { Appointment of } \\
\text { Prodi } \\
\text { (May 1999) }\end{array}$ & $\begin{array}{l}\text { Appointment of } \\
\text { Prodi } \\
\text { Commission } \\
\text { (Sep. 1999) } \\
\end{array}$ & $\begin{array}{l}\text { Appointment of } \\
\text { Barroso } \\
\text { Commission } \\
\text { (Nov. 2004) } \\
\end{array}$ & $\begin{array}{l}\text { Censure of } \\
\text { Santer } \\
\text { Commission } \\
\text { (Feb. 1997) }\end{array}$ & $\begin{array}{l}\text { Censure of } \\
\text { Santer } \\
\text { Commission } \\
\text { (Jan. 1999) }\end{array}$ \\
\hline Policy Difference-Left-Right & $-87.1 \%$ & $0.55 \%$ & $-5.75 \%$ & $-10.72 \%$ & $-43.56 \%$ & $11.78 \%$ & $41.45 \%$ \\
\hline Policy Difference-EU Integration & $-3.75 \%$ & $-93.42 \%$ & $-81.84 \%$ & $-96.89 \%$ & $-87.47 \%$ & $-98.67 \%$ & $-76.95 \%$ \\
\hline Left-Right Position & $94.7 \%$ & $16.54 \%$ & $-9.1 \%$ & $19.88 \%$ & $93.87 \%$ & $42.76 \%$ & $-62.66 \%$ \\
\hline MEP Support for EU Integration & $5.53 \%$ & $61.67 \%$ & $93.13 \%$ & $97.76 \%$ & $70.08 \%$ & $94.68 \%$ & $-4.18 \%$ \\
\hline National Party in the Commission & $4.78 \%$ & $5.67 \%$ & $-3.37 \%$ & $19.41 \%$ & & $32.92 \%$ & $30.22 \%$ \\
\hline National Party in the Council & $54.44 \%$ & $14.84 \%$ & $-2.5 \%$ & $19.54 \%$ & $36.35 \%$ & $3.52 \%$ & $26.33 \%$ \\
\hline
\end{tabular}

*Note: These data are the difference between the probability of supporting at the lowest value of the independent variable and the highest value of the independent variables.

To assess the relative power of the hypothesis more clearly, Table 4 shows the predicted probability of each independent variable. As these results shows, there is no clear characteristic of the MEPs supporting the Commission both at the start and at the end of its term. This contrasts with the features of a typical parliamentary government. In most cases, a parliamentary government starts its term with gaining supports from a majority of legislators who share certain-usually partisan affiliations. The government falls before its term ends if these legislators withdraw their supports. Usually the government finds it extremely difficult to gain supports from alternative sets of legislators. This is not the case for the Commission. As much as the Commission cannot be guaranteed to be in office by same groups of MEPs throughout its term, it is possible for it to survive a motion for censure by seeking support from MEPs that did not vote for its appointment.

\section{Conclusion}

The results support a "modified" parliamentary model. What I mean by "modified" is that the Commission (once it has been formed) should be regarded as a grand coalition, with broad partisan support in the European Parliament. Hence, in practice, the relationship between the EP and the Commission is a halfway house between a pure majoritarian parliamentary model and an independent agency/separation-of-powers model.

More specifically, policy differences between the Commission and the European 
Parliament are important in determining the fate of the Commission at the start and end of its term. Increasing policy divergence between the Commission and MEPs negatively affects the MEPs' support for the Commission. This suggests that the Commission may be removed from office if the ideological distribution of the MEPs changes during its term. With parallel terms of office for the Parliament and Commission, radical change in the policy divergence between the Commission and the Parliament cannot occur as a result of mid-term elections (as can be the case in other political systems). However, policy divergence can increase in the EU if there is a dramatic strengthening of a particular ideological dimension or the emergence of a new policy issue in the EU policy space.

Related to the issue of policy difference between the Parliament and the Commission, the partisan affiliation of MEPs and Commission does matter. In the appointment of the Commission, the candidates for the Commission President and the Commission as a whole can draw support from three groups: MEPs from governing parties, MEPs from parties that will have Commissioners, and MEPs from ideologically similar party groups in the Parliament (such as MEPs on the right who will support a centre-right candidate for Commission President).

This raises two interesting issues. First, the political make-up of the Parliament is often quite different to the political make-up of the Council. European elections are 'second-order national contests', and hence tend to be won by opposition parties (e.g. Marsh 1998). In other words, while governing parties are represented in the Council, the EP tends to be dominated by opposition parties. If the Council is a mix of left and right parties, then the make-up of the Parliament is unlikely to be radically different to the Council. However, if the Council is dominated by one side of the political divide, the European Parliament is likely to be dominated by the opposing side. For example, in 1999, when centre-left parties were in government in most member states, the centreright emerged as the dominant force in the post-1999 Parliament. However, the Prodi Commission was backed by the Parliament, despite being composed of a majority of politicians from the centre-left, because the governing parties on the right supported his nomination and backed their own candidates for Commission, and Prodi was regarded as a centrist political figure.

Second, and related, the results suggest that the shift in the Nice Treaty from unanimity voting to qualified-majority voting in the European Council for the nomination of a Commission President and the Commission as a whole with giving only one Commissioner to each member state as well as in the Lisbon Treaty to rotation of commissioners among member states (i.e. only two thirds of member states having 
"their" commissioners) should increase the influence of the European Parliament. Governing parties was found to be able to influence how MEPs vote, but that otherwise MEPs vote in the appointment and censure of the Commission along with national party or ideological lines. But, the coalition of governing parties in support of a particular Commission President or team of Commissioners will be smaller under a qualifiedmajority than under unanimity. Hence, this coalition of governments will be less able to impose its wishes on the European Parliament, because those governments in the Council in the losing minority will no longer have an incentive to lobby their MEPs to support the governments' candidate for Commission President or for the Commission as a whole. Also, with no opposition party having Commissioners any more due to the rule of one-Commissioner-per-country, the MEPs from those parties lose incentive to support the Commission. This will not make a difference if the political make-up of the Council and Parliament are similar. But, if the political make-up of the Parliament and Council are different, the Council will have to compromise with the Parliament much more than they did before. This has been already shown to a certain extent in the event when the Italian government was forced to withdraw its first Commission candidate for the Barroso Commission by the European Parliament. This lack of guaranteed support in the EP will signify when one thirds of the member states have no Commissioner of their own choice under the Lisbon Treaty. 


\section{REFERENCES}

Baron, David P. 'Government Formation and Endogenous Parties'. American Political Science Review 87- 1 (1993).

Baron, David P. 'Comparative Dynamics of Parliamentary Governments'. American Political Science Review 92-3 (1998).

Bergman, Torbjorn. 'Formation rules and minority government' . European Journal of Political Research 23-1 (1993).

Budge, Ian et al. Mapping Policy Preferences: Estimates for Parties, Electors and Governments 1945-1998. Oxford: Oxford University Press, 2001.

Budge, Ian et al. Mapping Policy Preferences: Estimates for Parties, Electors, and Governments in Eastern Europe, European Union, and OECD 1990-2004 Oxford: Oxford University Press, 2006.

Crombez, Christophe. 'Legislative Procedures in the European Community'. British Journal of Political Science 26-2 (1996).

Crombez, Christophe. 'Policy Making and Commission Appointment in the European Union'. Aussenwirtschaft 52-1/2 (1997).

Crombez, Christophe and Simon Hix. 'Unaccountable Brussels Bureaucrats? Implications of EU Constitutional Reforms on the Accountability of the Commission'. Unpublished memo (2003).

Diermeier, Daniel and Timothy J. Feddersen. 'Cohesion in Legislatures and the Vote of Confidence Procedure'. American Political Science Review 92-4 (1998).

Diermeier, Daniel, and Randy T. Stevenson. 'Cabinet Survival and Competing Risks' . American Journal of Political Science, 43-4 (1999).

Franchino, Fabio. 'Control of the Commission's Executive Functions: Uncertainty, Control and Decision Rules'. European Union Politics 1-1 (2000).

Gabel, Matthew J. and Simon Hix. The European Parliament and Executive Politics in the EU: Voting Behaviour and the Commission President Investiture Procedure. In Madeleine Hosli, Adrian Van Deemen and Mika Widgrén (eds), Institutional Challenges in the European Union. London: Routledge, 2002.

Grofman, Bernard, and Peter Van Roozendaal. "Toward a theoretical explanation of premature cabinet termination' . European Journal of Political Research 26-1 (1994). 
Hix, Simon. 'Executive Selection in the European Union: Does the Commission President Investiture Procedure Reduce the Democratic Deficit?' European Integration On-line Papers 1 (21). http://eiop.or.at/eiop/texte/1997-021a.htm. (1997).

Hix, Simon and Christopher Lord. 'The Making of a President: The European Parliament and the Confirmation of Jacques Santer as President of the Commission'. Government and Opposition 31-1 (1995).

Hix, Simon, Abdul Noury and Gérard Roland. 'How to Choose the European Executive: A Counterfactual Analysis, 1979-1999'. In Charles Blankart and Dennis Mueller (eds), A Constitution of the European Union. Cambridge, MA: MIT Press, 2004.

Hix, Simon, Abdul Noury and Gérard Roland. Democratic Politics in the European Parliament. Cambridge: Cambridge University Press, 2007.

Huber, John. 'The Impact of Confidence Votes on Legislative Politics in Parliamentary Systems'. American Political Science Review 90-2 (1996).

Judge, David, and David Earnshaw. The European Parliament and the Commission Crisis: A New Assertiveness'. Governance 15-3 (2002).

Kreppel, Amie and George Tsebelis. 'Coalition Formation in the European Parliament'. Comparative Political Studies 32 (1999).

Laursen, Finn. 'The Role of the Commission' . In Svein S. Andersen and Kjell A. Eliassen (eds). The European Union: How Democratic Is It?. London: Sage, 1996.

Laver, Michael, and Kenneth Shepsle. Making and Breaking Governments. Cambridge: Cambridge University Press, 1996.

Laver, Michael, and Kenneth Shepsle. 'Events, Equilibria, and Government Survival' . American Journal of Political Science 42-1 (1998).

Laver, Michael, and Kenneth Shepsle. 'Ministrables and Government Formation: Munchkins, Players and Big Beasts of the Jungle' . Journal of Theoretical Politics 12-1 (2000).

Magnette, Paul. 'Appointing and Censuring the European Commission: The Adaptation of Parliamentary Institutions to the Community Context' . European Law Journal 7-3 (2001).

Marsh, Michael. 'Testing the Second-Order Election Model after Four European Elections' . British Journal of Political Science 28-4 (1998).

Moury, Catherine. 'Explaining the European Parliament's Right to Appoint and Invest the Commission'. West European Politics 30-2 (2007).

Neunreither, Karlheinz. 'Governance without Opposition: The Case of the European Union' . Government and Opposition 33-4 (1998). 
Ringe, Nils F. 'Government-Opposition Dynamics in Executive-Legislative Relations of the EU. The Santer Commission Resignation Crisis'. European Journal of Political Research 44-5 (2005).

Schofield, Norman. 'Political Competition and Multiparty Coalition Government'. European Journal of Political Research 23-1 (1993).

Warwick, Paul V. 'Ministerial Autonomy or Ministerial Accommodation? Contested Bases of Government Survival in Parliamentary Democracies'. British Journal of Political Science 29 (1999). 